\title{
СЛОВЕНСЬКЕ ДЕРЖАВОТВОРЕННЯ У МІЖВОЄННИЙ ПЕРІОД: ПОГЛЯД КРІЗЬ «ВІКНА МОЖЛИВОСТЕЙ»
}

\begin{abstract}
Анотація: Процес відновлення словенського державотворення почався у серпні 1918 р., пройшов через чотири «вікна можливостей» $і$ залишився незавершеним в умовах запланованого розшматування словенських земель між Італією, Німеччиною, Угорщиною та Хорватією у 1941 p. Незавершеність обумовлювалася нерішучістю словенської національно-політичної програми, розколом словенського політикуму на течії югославізму та «словенства» і корінилося у впевненості словенського народу у своїй «неісторичності».

«Вікна можливостей» державотворчого процесу показують його «хвильовий» характер: він відновився та прискорювався у часи внутрішньополітичного хаосу - розвалу мультинаціональних державних утворень, у рамках яких жив словенський народ, в умовах посилення зовнішньої загрози на всьому протязі словенського північного кордону з боку Італії, Австрії, Угорщини, на тій (більшій) частині словенських земель, які стали складовою держави, спільної зі спорідненими слов'янськими народами (хорватами та сербами). Відтак, в умовах стабільного існування у мультинаціональних державах з авторитарним режимом процес словенського державотворення уповільнювався.
\end{abstract}

Ключові слова: Словенія, державотворення, югославізм, словенство, балканізм, «вікна можливостей»

В історії кожного народу обов'язково виділяються періоди, що вирішальним чином позначаються на його подальшій історико-політичній долі. Такі періоди стають предметами історіографічної легендаризації й або замовчуються, або вивчаються однобічно. Саме така роль в історії усієї Південно-Східної Європи належить міжвоєнному періодові. Цей період став доленосним для народів Західних Балкан. Для Словенії випала найважча доля. Ї̈̈ землі та народ було «розшматовано» між чотирма державами, вони втратили шанс захистити свою мову та культуру від югославської уніфікації в умовах авторитарної держави, яка обгрунтовувала свою централізованість саме цією уніфікацією.

Проблема словенського державотворення у міжвоєнну добу є слабовивченою навіть у словенській історіографії․․ Якщо узагальнити погляди югославських істориків на державно-політичний розвиток Словенії у 1918-1941 рр., головним висновком було слідування сербській позиції щодо партійної діяльності за часів Першої Югославії: саме парламентаризм і запекла партійна боротьба призвела до катастрофічних наслідків, сепаратизму, диктатури та поразки Першої Югославії у цілому. Це слугувало добрим теоретичним

\footnotetext{
"Мальшина Катерина Володимирівна - доктор історичних наук, доцент, Інститут української археографії та джерелознавства імені М.С. Грушевського НАН України;

ORCID: https://orcid.org/0000-0003-3004-3944; e-mail: kata_mascot@i.ua

${ }_{1}^{1}$ Мальшина К.В. Історіографія політичної історії Словенії I пол. XX ст. // Наукові зошити іст. ф-ту Львівського ун-ту. 2012-2013. Вип. 13-14. С. 511-522.
} 
підгрунтям для виправдання однопартійної системи та югославізму. За останні три десятиліття у даному напрямку досягнуто значних результатів у вивченні міжвоєнної історії Словенії. Але ще рано говорити про повне розуміння процесу словенського державотворення у цей період.

Ми розуміємо відновлення словенського державотворення як відтворення головних гілок словенської національної державної влади - законодавчої, виконавчої та судової, серед яких дослідження зосереджено на перших двох. У міжвоєнний період, в умовах політичної стагнації Першої Югославії, словенська державна влада зводилася до ростків самоуправління, розмір яких залежав від балансу політичних сил при різних режимах правління у Королівстві Югославія. Завдання ми бачимо у прослідкуванні процесу словенського державотворення у 1918-1941 рр. крізь «вікна можливостей».

Історичні процеси на словенських землях, з утворенням словенської ранньофеодальної держави Карантанії у 623 р., призвели до створення належних гілок державної влади - законодавчої, виконавчої та судової. Історична спадковість словенської державності, яка існувала до кінця Першої світової війни тільки на рівні історичного оповідання, була вивчена та доведена у 1920-30-і роки видатним словенським медієвістом Йосипом Малєм. Він знайшов докази «історичності» словенського народу, незважаючи на протидію 3 боку пануючого державного інтернаціоналізму в обох Югославіях. Це поступово ідеологічно визволило словенський народ від зашореності щодо свого власного державного минулого й обгрунтувало словенську національну ідею на історично-правовій основі².

Особливістю предмета дослідження є те, що необхідно пов'язати в єдине ціле одноразовість самого факту відновлення словенського державотворення у 1918 р. та його подальшу дискретність і незавершеність до 1941 р. Це дозволяє розглянути процес державотворення як динамічну предметну область через побудову її моделі. Динамічна предметна область є поняттям темпоральної логіки, яке відображає розвиток реального світу. Розумінню механізму цього «хвильового» процесу слугує конкретний метод темпорального моделювання. Ми будуємо цю модель у континуїтеті визначеного періоду; виявлення проявів (хронологічних «вікон можливостей») і причин його дискретності; а також сукупності факторів його неуспішності. Ї̈̈ побудова вимагає, перш за все, визначення хронологічних рамок.

Хронологічні межі - 1918-1941 рр. обрані у відриві від усталеної хронології міжвоєнного періоду, який для Європи традиційно визначається кінцем Першої світової війни на європейських фронтах у перші дні листопада 1918 р. та початком Другої світової війни у вересні 1939 р. або вступом певної держави у війну, для Югославії це 6 квітня 1941 р. Логіка та динаміка словенського державотворчого процесу, що відновився у серпні 1918 р. (початкова дата) у вигляді створення «серпневої» Національної ради СХС в Любляні, вимагає встановлення кінцевої дати дослідження у вересні 1941 р., коли керівники вже другої, «квітневої» Національної ради для Словенії, залишили легальну політичну сцену, і рада остаточно пішла у підпілля. Обидві дати пов'язані з кульмінаційними кризовими

\footnotetext{
${ }^{2}$ Мальшина К.В. Історія у боротьбі з югославізмом: Йосип Маль та його внесок у вивчення традиції словенської державності // Історичний архів. 2014. Вип. 12. С. 148-155.
} 
моментами розвалу державних утворень, у яких перебувала Словенія, i, таким чином, є найбільш широкими «вікнами можливостей».

Одне 3 політологічних понять - «вікна можливостей» - є суттєвим для розгляду процесу відновлення словенського державотворення, як динамічної предметної області. Концепцію «вікон можливостей» розробив віце-президент МакКінакського центру громадської політики (Мідланд, США) Джозеф Овертон наприкінці ХХ ст., в якості виборної політичної технології, тому цей тип назвали «вікна Овертона». Головна ідея полягає у тому, що не політики, а запити суспільства впливають на вибір державного курсу. «Вікно Овертона описує... одну велику річ: політики не завжди будуть підтримувати будь-яку політику...; навпаки, вони будуть робити щось без ризику поразки на виборах, з урахуванням тодішнього політичного середовища, сформованого ідеями, соціальними рухами та соціальними відчуттями».

«Вікно Овертона» за змістом примикає до ширшого поняття «вікна можливостей» у всьому різноманітті його застосування, багато у чому з ним перетинаючись Поняття «вікна можливостей» є об'ємнішим, по-перше, це «прикладна» політтехнологія, а по-друге, вона характеризується «процесуальністю».

Для розгляду історичних процесів, ми визначаємо «вікно можливостей», як цілісний буттєвий (історичний) феномен з межами його здійснення, тобто досягнення повної ймовірності його реалізації. У цьому методологічному фокусі, усі спроби словенців у 1918-1941 рр. поновити процес державотворення слід розуміти, безумовно, не як разові окремі історико-політичні акції, але як події, що мали дуже складну перед- і післяісторію та являли собою обсяговий феномен з чіткими межами існування, всередині яких були можливі різні вектори руху".

Передумови для відновлення словенського державотворчого процесу склалися у період 1848-1918 рр. По перше, у «Програмі Об’днаної Словенії 1848 р. було сформульовано словенську національно-державну ідею (об'єднання всіх етнічних словенських земель в єдину адміністративну одиницю зі своїм парламентом і визнання словенської мови, тобто повна національна автономія).

По-друге, сформувалися рушійні сили процесу - головні політичні табори, чиї програми були орієнтовані, у тому чи іншому ступені, на створення єдиної національної державної одиниці: клерикальний, ліберальний і робітничий. Консервативний табір мав підтримку серед великих, середніх і частини дрібних землевласників, католицького духовенства, а також частини інтелігенції. Ліберальний табір спирався на дрібнобуржуазну соціальну базу. Робітничий (або комуністичний) табір, як і в інших державах світу, мав пролетарську соціальну базу, яку доповнювала міська інтелігенція.

Словенські політичні табори у 1918-1941 рр. поділялися на 2 течії - націоналізм, або «словенство», та югославізм, тобто національна уніфікація габсбурзьких слов'ян. Ці напрямки бачили різні шляхи до Об’єднаної Словенії. Автономісти (клерикальний табір - Словенська Народна партія, далі СНП) за національну ідею мали «словенство», за державну -

\footnotetext{
${ }^{3}$ Lehman J.G. An Introduction to the Overton Window of Political Possibility // Mackinac Center for Public Policy Journal online. April 8, 2010. URL: https://www.mackinac.org/12481

${ }^{4}$ Мальшина К.В. Процес відновлення словенського державотворення 1918-1941: дис... д.і.н. Київ: ІУАД НАНУ. 2019. C. 112-114.
} 
Об'єднану Словенію, у політиці способом досягнення цієї мети було виконання Корфських домовленостей травня 1918 р., тобто федеративного устрою майбутньої Югославії.

Централісти-югославісти (ліберали) думали, що лише уніфікована югославська нація у централізованій державі могла надати словенцям можливість виживання та розвитку.

Комуністичний табір, з 1921 р. нелегальний, спочатку підтримував югославізм, грунтуючи його на принципі інтернаціоналізму, але з 1923 р. перейшов на жорсткі націоналістичні позиції. Позиції клерикалів і комуністів часто збігалися, хоча і 3 протилежних підстав. У 1945 р. комуністи перебрали на себе програму клерикалів і намагалися втілити iï у життя.

\section{I. ПЕРШЕ «ВІКНО МОЖЛИВОСТЕЙ»}

Державотворчі процеси на словенських землях відновилися у серпні-листопаді 1918 p. Сенсом цих процесів було створення перших національних державних органів і поступове формування та розвиток головних гілок влади - законодавчої («серпнева» Національна Рада в Любляні), виконавчої (Національний уряд в Любляні, Національна брамба (оборона), військове командування, поліція) та судової. Ці процеси протікали на словенських землях у складі Держави СХС, мультинаціонального утворення, що мало конфедеративний характер і всі ознаки буржуазно-демократичної республіки.

Час існування Держави СХС, як ще у 1923 р. писав відомий словенський публіцист та історик Фран Ерьявець, можна справедливо помістити між найкращих розділів словенської історії5. Словенці на короткий час «доби перевороту», як ї̈ найменував інший відомий словенець А. Препелюх, покладалися винятково на свої сили та свої можливості й у цьому випробуванні виявилися блискучими організаторами ${ }^{6}$. Доба з серпня 1918 р. по січень 1919 р. у словенській історії виявилася найбільш плідною у державотворчому сенсі.

У рамках Держави СХС була здійснена повна автономія більшої частини Словенії (за винятком окупованих Примор'я, Каринтії та Прекмур'я). На внутрішньополітичній сцені новостворені словенські органи влади вирішили майже всі питання формування держави: створення власної адміністративної, судової системи на місцях і структур охорони порядку, формування словенських збройних сил, початок встановлення державних кордонів. Словенська мова стала державною. Особливістю їхньої діяльності було те, що вона виходила за хронологічні рамки існування Держави СХС. Перша у словенській історії Національна рада діяла з 16 серпня 1918 р. по 30 квітня 1919 р., у чому словенці випередили інших габсбурзьких слов'ян, Національний уряд також працював ще деякий час після утворення Королівства СХС (1 грудня 1918 р. - 23 січня 1919 р.).

На міжнародну арену словенці (в особах своїх найвидатніших політиків) вийшли 3 метою подальшого вирішення свого національного питання - об'єднання всіх етнічних словенських земель у єдину державну одиницю ${ }^{7}$.

\footnotetext{
${ }^{5}$ Erjavec F. Slovenci: zemljepisni, zgodovinski, politični, kulturni, gospodarski in socialni pregled. V Ljubljani: Jugoslovanska knjigarna, 1923. S. 67.

${ }^{6}$ Prepeluh A. Pripombe k naši prevratni dobi: z zemljevidoma Koroške in Primorja. Ljubljana: J. Blasnik, 1938. $562 \mathrm{~s}$.

${ }^{7}$ Детальніше див.: Мальшина К.В. Особливості міжнародного становища Словенії у складі Держави СХС (жовтень-листопад 1918 р.) // Актуальні проблеми міжнародних відносин і зовнішньої політики країн світу: Матеріали міжнародної науково-практичної конференції (Луцьк, 13-14 жовтня 2011 р.). Луцьк: Вид-во ВНУ, 2011. C. 293-296.
} 
У внутрішній політиці формування власної законодавчої гілки влади мало завершитися як визнання Національної ради словенським парламентом. Ї̈ дійсні функції та методи діяльності у серпні-листопаді 1918 р. повністю відповідали цьому визначенню. Але спроби визнати «серпневу» Національну Раду за власний парламент, однак, залишилися на папері та загубилися у міжпартійних суперечках Національного уряду.

Це було найширше «вікно можливостей», яке вже ніколи не поновилося у подібному обсязі. На жаль, це «вікно» також закрилося занадто швидко (остаточно з прийняттям Відовданської конституції у 1921 р.), і багато словенських ініціатив не досягли свосї мети.

Вже $з$ перших днів у новій спільній державі - Королівстві СХС - повільно почався поступовий наступ на повну автономію словенців. Заміна Національного уряду СХС в Любляні Провінційним урядом для Словенії ліквідувала словенську автономію, стала початком запровадження централізації. 312 «повіренств» - «міністерств» залишилося 4, найбільш політично і економічно неважливі. «Таким чином, були ліквідовані останні елементи словенської державності, створені у боротьбі за визволення і об'єднання» ${ }^{8}$.

На югослов'янській політичній сцені спроби домогтися гарантій федеративноавтономного устрою провалилися. Велику роль у прискоренні югослов'янського об'єднання у формі монархії відіграв зовнішній чинник - італійська загроза словенському Примор’ю й Істрії та хорватській Далмації.

У зовнішній політиці довелося миритися з італійською окупацією Примор'я, не вдалося зайняти словенські землі - Каринтію та Прекмур'є.

Але попереду словенці чекали справедливого виконання своїх прагнень - жити своїм життям у Об'єднаній Словенії. Ці очікування вони тепер пов'язували з Паризькою мирною конференцією та Конституантою. Знов словенці чекали на вирішення доленосних питань від зовнішніх акторів.

Провінційному урядові довелося вирішувати всі державотворчі проблеми, успадковані від Національного уряду, але у набагато складніших внутрішніх і зовнішніх умовах.

Поступова централізація та інтенсивне втручання наддержав і сусідніх країн у процес визначення словенських кордонів призвели до поразки Провінційного уряду на всіх теренах. Уряд досягнув збільшення кількості дозволених повіренств 34 до 6, і, таким чином, вирізнився між іншими провінціями Королівства. Але сфера його адміністративної відповідальності не досягала попередньої повної автономії. Центральний уряд у Белграді зовсім припинив його діяльність 12 липня $1921 \mathrm{p}$.

Завершити процес об'єднання всіх словенців у єдиній країні теж не вдалося. Головною причиною було незвичайне положення словенських земель у міжнародному розкладі: протягом війни Словенія була частиною Австро-Угорщини, що потерпіла поразку у Першій світовій війні, і Сербія, як країна-переможниця, розглядала їі землі як розмінну монету у вирішенні власних територіальних проблем на Балканах, тому і військова, і дипломатична допомога сербів у відвоюванні словенських кордонів не була достатньою. 3 другого боку, Італія спільно з Австрією приклали усі зусилля для захоплення максимально можливої кількості словенських земель.

\footnotetext{
${ }^{8}$ Zečević M. Slovenska ljudska stranka in jugoslovansko zedinjenje 1917-1921: od majniške deklaracije do vidovdanske ustave. Maribor: Obzorja, 1977. S. 211.
} 
Рішення Паризької конференції на користь Австрії приймалися не заради Австрії, але проти Югославії, тому що її від початку підтримувала Франція. Справа у тому, що на конференції Королівство СХС в цілому сприймалося як розширене Королівство Сербія, i йшлося не про права народів, а про зростання впливу Франції на Балканах. Сама Сербія, вперше вийшовши на світову арену, ще не мала достатнього досвіду у дипломатичних баталіях; крім того, вона використовувала словенські землі в якості розмінної монети, щоб виторгувати територіальні поступки для себе на півдні, у Македонії. Так, словенські землі «розшматували» між собою 4 держави, і тільки у Королівстві СХС словенці отримали деяку квазісамоврядність.

За рішенням Паризької конференції 10 жовтня 1920 р. відбувся плебісцит у Каринтії - остання надія приєднати словенців, що залишалися в Австрії. Але проявилися наслідки багатовікового австрійського соціального та національного тиску на місцевих словенців, що прослідковується й сьогодні. Внутрішні причини цього концентрувалися навколо соціальної структури каринтійського суспільства, де малочисельне національно свідоме заможне селянство голосувало за СХC, а наймити та міщани - за Австрію. Крім того, агітували не за Словенію, а за Югославію (королівство, й, більше того, з православною династією на чолі), але каринтійці мали можливість залишитися у католицькій буржуазній республіці.

Програний Каринтійський плебісцит мав катастрофічні наслідки для словенського народу. За кордонами Словенії залишилося 40\% словенських земель і населення, у тому числі біля 1 млн. каринтійських словенців, що ускладнювало ставлення словенців до центральної влади, яку вони звинуватили у втраті Каринтії, та до сусідів по державним кордонам, які відтяли Каринтію (Австрія), Примор'є з Трієстом (Італія) і Пораб'є (Угорщина).

Поразка у плебісциті, яка для словенців символічно увібрала в собі й інші територіальні втрати, стала одним з вирішальних чинників уповільнення процесу словенського державотворення, процес об'єднання словенських земель залишився незавершеним.

\section{II. ДРУГЕ «ВІКНО МОЖЛИВОСТЕЙ»}

Розвиток словенського державотворення у 1920-ті рр. грунтувався на новому внутрішньо- та зовнішньополітичному становищі Словенії як залежної території з народом, за яким перестали визнавати його національну ідентичність. Тому друге «вікно можливостей» (1927-1929 рр.) мало досить довгий «переддень».

Боротьба словенського політикуму за збереження решток самоврядування й Об'єднану Словенію проходила у формі протистояння ідейно-політичних югославізму та «словенства».

У 1923-1925 рр. лави югославістів ще скоротилися. Цьому сприяв перехід словенських комуністів на націоналістичні позиції (1923 р.) та результати чесної передвиборчої боротьби у Національну скупщину 1925 р., які не надали бажаного ефекту через зовсім іншу політичну традицію - сербську (тобто особисті зв'язки, закулісні інтриги та політичне лавірування).

Використання недемократичних і конфліктуючих із мораллю принципів на рівні вищих ешелонів влади мало свій вплив на діяльність провідних акторів словенської полі- 
тики. Коли СНП зрозуміла спосіб винесення рішень у королівстві, її керівництво вдалося до політичних ігор, які були невід'ємною частиною політики Белграду. Головною метою було скористатися будь-якою нагодою, щоб прийти до влади в обласних органах самоврядування та вибороти якнайбільше прав і переваг для Словенії.

Тому автономісти, що опинилися в опозиції центральному урядові, вдалися до політичного лавірування. Після політичного бойкоту у 1921-1925 рр., СНП підписала політичну угоду з урядом про визнання конституції та влади короля (Бледська угода 1927 р.), за якою ціною визнання Відовданської конституції вступила у коаліційний уряд9. Таким чином, СНП досягла політичного панування у Люблянській і Маріборській областях. Робота у центральному уряді уможливлювала значні переваги партії на місцях і сприяла виконанню автономістської програми. Це відкрило друге «вікно можливостей» для нової хвилі словенського державотворення. Успіхом такої тактики було особливо широке фінансування заходів і розширення законодавчої юрисдикції скупщин Люблянської та Маріборської областей, через що югослов'яни почали іменувати Словенію «державою у державі».

Діяльність обох словенських обласних скупщин відрізняли характерні особливості: парламентські методи роботи, намагання синхронізувати діяльність обох скупщин через синхронність проведення засідань, постійна боротьба з центральним урядом за розширення своїх повноважень.

На жаль, після королівського перевороту 6 січня 1929 р. скасування фундаментальних буржуазно-демократичних основ у Югославії та початок репресій різко загострили протистояння словенських централістів та автономістів. Додатковим каталізатором був початок Великої економічної кризи та різке погіршення соціально-економічних умов у Словенії. Програми словенських політичних таборів теж набули більшої категоричності. Словенська клерикальна опозиція, яка послідувала за хорватською у відкритому виступі проти унітаризму та централізму режиму особистої диктатури короля Олександра, програла. Ії̈ керівники були репресовані.

На фоні загальної стагнації політичного життя, здавалося б, жодної нової можливості для відновлення навіть мінімальних ростків самоврядування не могло виникнути. Єдиним органом влади, де словенці могли висловлювати свої думки та приймати деякі рішення, стала Банська рада Дравської бановини, яка офіційно мала тільки консультативні функції, розглядаючи лише важкі соціальні проблеми, викликані економічною кри$30 ю$.

Однак, у 1933-1935 рр. діяльність банської ради суттєво політизувалася. На слуханнях деякі дискусії набули політичні дименції, зокрема, щодо обов'язків і повноважень бановини та місцевого самоврядування, виборів бановинської ради, державної фінансової політики по відношенню до Словенії.

Олександру I необхідно було знайти шляхи поліпшення внутрішньополітичної ситуації, при цьому зберегти всю повноту влади і підняти рівень своєї популярності серед населення та за кордоном. Тому у 1933 р. влада була змушена вдатись до демонстрації

\footnotetext{
${ }^{9}$ Мальшина К.В. Національне державотворення у поглядах та політичній діяльності словенського клерикалізму (1918-1929 рр.) // Наукові праці іст. ф - ту 3НУ. 2013. Вип. XXXVI. С. 264-271.
} 
повернення до демократії - виборів у муніципальні ради, найнижчого рівня адміністративної відповідальності. Для цього уряд надав банським радам повноваження щодо прийняття постанов, що стосувалися різних аспектів проведення виборів. Це означало розширення компетенцій банської ради Дравської бановини у законодавчому напрямку.

Влада використала вибори для прикриття реформи з об’єднання дрібних муніципалітетів, яка заощаджувала державні бюджетні кошти, але погіршувала соціальноекономічну ситуацію у Словенії, гірській, зі слабкою інфраструктурою. Але, навіть у напів-забороненому положенні, автономісти все ж скористувалися нагодою, отримали міцну підтримку населення та зайняли багато важливих посад у муніципалітетах, укріпилися у прагненні знайти шляхи, щоб знову почати активну діяльність. Процент мандатів, отриманих опозицією у Словенії, був найвищий по Югославії ${ }^{10}$.

У цілому ж треба відзначити, що автономістські зусилля Банської ради Дравської бановини були обумовлені, зокрема, її партійним складом i, особливо, наслідками зміни правлячих режимів.

\section{III. ТРЕТЕ «ВІКНО МОЖЛИВОСТЕЙ»}

1930-ті роки являли собою поворотний пункт в ідейних поглядах у Європі. Ліберальна демократія втратила довіру, на перший план вийшли прихильники класових бачень, що людина повинна підпорядковувати свої інтереси колективові - громаді, класу, нації. Прихильність як до станової корпоративної, так і до класової організації, означала відмову від індивідуалізму й обмеження демократичних свобод. Це глобальне явище не оминуло й Югославію, а з нею і Словенію, особливо після вбивства короля Олександра восени $1934 \mathrm{p}$.

Після вбивства Олександра I словенські клерикали-автономісти отримали можливість вийти з багаторічної опозиції і знову вступити у політичне життя. Єдиним шляхом для цього було приєднання до вседержавної партії - Югославський Радикальний союз $(\mathrm{HPC})^{11}$.

Рішення незмінного голови СНП А. Корошця увійти до ЮРС та уряд М. Стоядиновича у 1935 р. доленосно відзначили тодішні політичні події у Словенії ${ }^{12}$ Це дозволило відкрити наступне «вікно можливостей» для виборення словенської автономії, i, як з'ясувалося, за прикладом Хорватії.

Конкордатська криза 1935-1937 рр. надала підгрунтя для хорватського сепаратизму, який проявився у створенні Бановини Хорватії, в обхід Октройованої конституції, відповідно до угоди Цвєтковича-Мачка від 26 серпня 1939 р. Цей прецедент став причиною

\footnotetext{
${ }^{10}$ Gašparič J. SLS pod kraljevo diktaturo. Diktatura kralja Aleksandra in politika Slovenske ljudske stranke v letih 1929-1935. Ljubljana: Modrijan, 2007. S. 201.

${ }^{11}$ Vodušek Starič J. Liberalni patriotizem in intrasigenca 1. 1941 // PNZ. 2001. Št. 2: Slovenci in leto 1941. S. 63; Godeša B. Kdor ni z nami, je proti nam: slovenski izobraženci med okupatorji, Osvobodilno fronto in protirevolucionarnim taborom. V Ljubljani: Cankarjeva založba, 1995. S. 46-52; Vodopivec P. Od Pohlinove slovnice do samostojne države: slovenska zgodovina od konca 18. stoletja do konca 20. stoletja. Ljubljana: Modrijan, 2006. S. 224-237.

${ }^{12}$ Gašparič J. SLS pod kraljevo diktaturo... S. 245; Ahčin I. Izgubljeni spomin na Antona Korošca: iz zapuščine Ivana Ahčina // Bojan Godeša, Ervin Dolenc (ur.). Ljubljana: Nova revija, 1999. S. 150.
} 
висунення питання про створення Бановини Словенії ${ }^{13}$. Приводом для цього була постанова центрального уряду про поширення права на створення національної бановини на інші народи Югославії ${ }^{14}$. Умовою була своєчасна підготовка усіх необхідних документів ${ }^{15}$ для затвердження регентом, поки словенська політична еліта мала вплив у центральному уряді, особливо в особі Корошця. Активна постановча підготовка до створення бановини Словенії велася Банською радою, яку на цей час переважно складали клерикали.

Питання Бановини Словенії примусило клерикальний табір шукати державнополітичну модель словенського суспільства, розглядаючи приклади розв'язання національного питання, які надавала Європа у другій пол. 1930-х років. Після падіння Польщі клерикали, у турботі про самозбереження остаточно схилилися до прикладу виживання Словаччини через її католицько-соціальну модель з елементами європейської демократії та прилаштування до нацистського «Нового порядку» . $^{16}$

Початок Другої світової війни поступово відвернув фокус політики белградського уряду на міжнародну арену, і процес створення бановини Словенії було згорнуто. Не останню роль у цьому зіграла смерть А. Корошця 14 грудня 1940 р. Ще одне «вікно можливостей» закрилося.

\section{IV. ЧЕТВЕРТЕ «ВІКНО МОЖЛИВОСТЕЙ»}

Останнє «вікно можливостей» словенського державотворення було пов'язано зі спробою відновити національну автономію під час нацистсько-фашистської окупації Словенії у квітні - вересні 1941 p.

У зовнішньополітичному погляді СНП допускала можливість перемоги держав Осі та нового порядку в Європі. Після перевороту в Югославії 27 березня 1941 р. СНП змінила тактику - у випадку окупації керівництво партії вирішило не йти на співпрацю з окупантом і виконати свій громадянський обов'язок перед Югославією.

Але на початку Квітневої війни 1941 р. вторгнення окупантів до Югославії почалося саме через територію Словенії. Державотворча програма СНП на період війни, поспіхом сформульована у складних внутрішньополітичних обставинах в останній день перед початком окупації, базувалася на декількох принципах, головними з яких були у будь-який спосіб збереження єдності словенського народу; збереження фізичного складу населення, економіки та інфраструктури, запобігання кровопролиттю.

Поразка самостійницької політики, тобто уповільнення та припинення процесу словенського державотворення у 1919-1920 рр., заклало підгрунтя для подальшого поновлення цього процесу у подібних умовах у квітні 1941 р., але вже на основі колабораціонізму. Та частина керівників, яка залишилася на батьківщині разом з баном М. Натлаченом,

\footnotetext{
${ }^{13}$ Детальніше див.: Мальшина К.В. Питання бановини Словенії у поглядах словенського політикуму (19371940 рр.) // Гуржіївські історичні читання. Вип. 8-9. 2014-2015. С. 213-219.; Мальшина К.В., Волобуєв В.В. Бановина Словенія: нездійснена мрія про словенську автономію у Першій Югославії (1939-1940рp. ) // Наукові записки Національного університету «Острозька академія». Серія: Історичні науки. 2015. Вип. 24. С. 163-169.

${ }^{14}$ Perovšek J. Jugoslovanska nacionalna stranka in vprašanje slovenske banovine 1939-1941 // Prispevki za novejšo zgodovino.2002. Št. 3. S. 49-59.

${ }^{15}$ Gosar A. Banovina Slovenija: politična, finančna in gospodarska vprašanja. Ljubljana: Dejanje, 1940.39 s.

${ }^{16}$ Godeša B. Tisova Slovaška 'priljubljeni sen slovenskega klerofašizma // Zgodovinski časopis. 2004 Št. 1-2. S. 6980.
} 
у спасінні словенського народу обрала в якості способу виживання повну незалежність, очевидно, за прикладом Словаччини, а тимчасове рішення бачила під егідою окупантів. Під впливом інформації про неспроможність Югославії протистояти нападу, а також про нацистські плани створити із Словенії протекторат, СНП змінила патріотичні плани на націоналістичні: створення єдиної, неподільної, незалежної словенської (можливо, спільної з хорватами) держави під одним окупантом. Політичною тактикою було обрано продовження позитивної традиції з часів Держави СХС, тобто створення багатопартійної Національної ради ${ }^{17}$.

Завданням Національної ради для Словенії було взяти владу у Словенії та вжити всіх необхідних заходів для виконання стратегічного плану СНП.

В очах югославського уряду, хоча з ним було перервано прямий зв'язок, існування Національної ради для Словенії було неприйнятним, не могло бути і не було визнано урядом, оскільки жоден офіційний закон югославського законодавства не передбачав двовладдя. Створення Національної ради для Словенії стало державотворчим кроком, який не поновив жоден народ Югославії. Національна рада, таким чином, була винятком на югославському терені.

3 проголошенням суверенітету Дравської бановини, бан і Національна рада фактично відмовилися підпорядковуватися Белграду. 3 перетворенням Національної ради в уряд i спробою сформувати словенську армію (з організацією Словенського легіону) були вжиті кроки для реалізації плану Обєднаної Словенії як «своєрідного німецького протекторату».

Роботу Національної ради під час Квітневої війни (6-17 квітня 1941 р.) можна розглядати поетапно: спочатку хорвати поспішили зі створенням Незалежної Держави Хорватії і плани спільної словенсько-хорватської держави провалилися. Створенню Незалежної Словенії стала на заваді неочікувана італійська окупація західної Словенії разом 3 Любляною. Спроби радників об'єднати Словенію під єдиною окупаційною владою, спочатку нацистською, потім фашистською, також провалилися.

Італійські окупанти заборонили Національну раду, але пообіцяли визнати словенську автономію та створили радний орган - Консульту (дорадчий орган при голові італійської окупаційної влади в Любляні), до якої увійшли представники Національної ради. Через це можна було б вважати Консульту легальним продовженням у той час вже нелегальної ради.

Через провал всіх своїх планів СНП знов прийшла до визнання уряду Югославії в екзилі. На наш погляд, цей програмний державотворчий принцип було прийнято вимушено - оскільки Національну раду не визнали окупащійні влади.

Після нападу Німеччини на СРСР і розширення операцій партизанського руху, умови італійської окупації змінилися на гірші й у вересні 1941 р. головні актори словенської політики - керівники головних словенських політичних таборів залишили Консуль$\mathrm{Ty}^{18}$, що можна вважати кінцевою точкою легальної словенської державотворчої діяльності у міжвоєнний період.

\footnotetext{
${ }^{17}$ Ivešić $T$. Delovanje dr. Franca Kulovca na čelu SLS in ključni dogodki pred vojno // Časopis za zgodovino in narodopisje. 2013. Št. 1. S. 83-118.

${ }^{18}$ Griesser-Pečar T. Razdvojeni narod. Ljubljana: Mladinska knjiga, 2004. S. 72-80.
} 
Таким чином, бачимо, що процес відновлення словенського державотворення у 1918-1941 рр. протікав складно та нелінійно, з просуванням вперед і відступами, що дозволило побудувати модель динамічної системи політичних відносин усередині словенського суспільства та відносин словенського суспільства із зовнішнім середовищем, як всередині Першої Югославії, так і поза її кордонами.

Каталізатором всіх процесів словенської національної емансипації стала Перша світова війна. Ї̈̈ останній період і післявоєнний переустрій Європи визначним чином вплинули як на державно-політичні ідеї, які виробили словенці за весь попередній час 3 середини XIX ст., так і на процес їхнього уточнення та втілення у міжвоєнний період.

Вагомим зовнішнім чинником процесу відновлення словенського державотворення ми бачимо у відношенні міжнародних акторів у XIX - першій пол. XX ст. до словенців та їхніх етнічних земель як до розмінної монети у міждержавній торгівлі кордонами, в якій брали участь Австрія, Угорщина, Італія, Хорватія та Сербія, а також країни Антанти, що є, у свою чергу, наслідком «неісторичності», або, скоріше, недоведеності «історичності» та малочисельності словенського народу.

Це, у свою чергу, також вплинуло на такі особливості відновлення державотворчого процесу, як обмеженість словенської території, де відновився процес, та пошуки партнерів для захисту єдності словенських земель спочатку поза Австрією, яка виявилася неспроможною гарантувати цю єдність, а пізніше - поза Королівством Югославія.

Через критерії розвитку словенської національної та державної ідеї у політичній практиці ця модель дозволяє визначити хронологічні «вікна можливостей» для відновлення словенського державотворення.

Першим «вікном можливостей» словенці скористалися у кордонах Держави СXC, коли були створені перші в історії національні демократичні органи влади. У серпнілистопаді 1918 р. склалася цікава унікальна колізія, яка стосувалася розподілу повноважень між словенськими Національною Радою та Національним урядом, і в той же час між словенськими органами влади та загребським Національним Вічем. Фактично це було питання про незалежність словенської буржуазно-демократичної республіки або їі повну автономію у складі федеративної Держави СХС. У результаті дискусії Національний уряд прийняв резолюцію про виконавчу підпорядкованість Національному Вічеві у Загребі та консультативну роль власної Національної Ради.

Можна зробити висновок, що відновлення державотворення на словенському політичному просторі у часи перебування словенців у Державі СXС мало специфічний характер - воно проходило як генеза словенської державності у формі буржуазної республіки у складі мультинаціональної федерації габсбурзьких слов'ян. Внутрішні та зовнішні чинники зумовили специфічну рису цього процесу - він проходив на основі спільної політичної практики, а не теорії, тобто емпірично, через власний унікальний досвід. Політична практика показала, що наявність зовнішнього законодавчого органу - Національного Віча CXC у Загребі - вказувала на злободенну актуальність саме Національного уряду у Любляні. Національна Рада відбулася б в якості словенського парламенту тільки у тому разі, якщо словенці наважилися б на створення власної суверенної держави.

Наступна можливість видалася тільки у 1927-1929 рр., коли було дозволено обрати 
Люблянську та Маріборську обласні скупщини. Виборність регіональних самоврядних органів була значним досягненням політичної боротьби словенських депутатів (разом 3 хорватськими) у Конституанті. Територія Словенії у цей час була розділена на дві області, що було кроком назад з адміністративної точки зору. Тому головними завданнями керівництва обласних скупщин була синхронізація діяльності обох скупщин, особливо у прийнятті єдиних рішень по всім питанням, що було кроком вперед у розвитку словенського парламентаризму, наскільки це було можливо за Відовданською конституцією.

Третя можливість для продовження державотворчого процесу в Словенії знов відкрилася зі створенням Дравської бановини та їі Банської ради. Дравська бановина об’єднала всі словенські землі під єдиною адміністрацією, що було кроком вперед у цьому аспекті, але у відношенні виборного представництва та постановчих повноважень Октройована Конституція була автократичною. У цих умовах Банська рада була тим осередком, де повільно, але поступово у 1930-х роках відновлювався процес словенського державотворення. Кульмінацією цього процесу стала підготовка до створення Бановини Словенії у 1939-1941 pp.

Для цього склалися необхідні внутрішньополітичні умови: Конкордатська криза 1935-1937 рр. надала тверде підгрунтя для хорватського сепаратизму, який проявився на легальному рівні у створенні Бановини Хорватії, в обхід Октройованої конституції. Цей прецедент став причиною висунення питання про створення Бановини Словенії (19391941 рр.), теж католицької. Приводом для прискорення цього процесу була постанова центрального уряду про поширення права на створення національної бановини на інші народи Югославії. Умовою іiї створення зі словенського боку була своєчасна підготовка усіх необхідних документів для затвердження регентом, поки словенська політична еліта мала вплив у центральному уряді, особливо в особі Корошця.

Зовнішньополітичні фактори, однак, складалися не на користь словенських намагань. Проголошення автономії Словаччини у жовтні 1938 р., а у березні 1939 р. - республіки, разом з окупацією Чехії, окупація та перекроювання кордонів Польщі міцно посилили побоювання словенської політичної еліти щодо можливості повторення подібних сюжетів на теренах Югославії. 3 другого боку, окупація Франції у травні 1940 р. та зростання загрози залучення Югославії до війни, а також смерть Корошця, тобто відсутність зовнішньополітичного та внутрішньополітичного гарантів стабільності життя у Словенії, підштовхнули керівництво СНП шукати модель виживання у разі вступу Югославії до війни.

Остання, четверта спроба відновлення словенської наиіональної автономії у перший період нацистсько-фашистської окупації Словенії (у квітні - вересні 1941 р.), остання з можливостей, закономірно випливала з невдалої спроби створення Бановини Словенії та була тісно пов'язана з кульмінаційним періодом у словенському державотворенні за часів «серпневої» Національної ради та Держави СХС. Але надії словенців на автономію під італійською окупацією були швидко втрачені. Жорстокість окупаційних режимів на словенських землях відняла останній шанс на створення Об'єднаної Словенії у рамках буржуазної демократії.

Причиною припинення словенського державотворчого процесу у кожному «вікні можливостей» був зовнішній фактор. У 1919-1940 рр. це була сербська політика держав- 
ної централізації та національної уніфікації. Режим диктатури додавав жорсткості рамкам, в які був загнаний політичний процес по всій державі. В останній раз, у квітні 1941 р., повне припинення будь-якого розвитку Словенії мало за причину нацистськофашистську окупацію.

Як бачимо, кризи відкривають вікно можливостей, і чим глибша криза, тим ширше це вікно. Саме політичні кризи в Австро-Угорщині (травень-листопад 1918 р.), Державі СХС (кінець листопаду 1918 р.) та Королівстві СХС / Югославії (1926, 1934, 1937, березень та квітень 1941 р.) відкривали «вікна можливостей» для поновлення словенського державотворення. Найгострішими були перша та остання з цих криз, і саме 3 ними пов'язана інтенсифікація цього процесу та діяльність двох словенських Національних рад - «серпневої» 1918 р. та «квітневої» 1941 р.

Відновлення словенського державотворення почалося наприкінці 1918 р., але не завершилося через нерішучість словенської національно-політичної програми, що обумовлювалося розколом словенського політикуму на течії югославізму та «словенства», що, у свою чергу, корінилося у впевненості словенського народу у своєї «неісторичності». Сукупність зовнішніх і внутрішніх факторів складалася таким чином, що процес словенського державотворення мав «хвильовий» характер: він відновився та прискорювався у часи внутрішньополітичного хаосу - розвалу мультинаціональних державних утворень, у рамках яких жив словенський народ (Австро-Угорщина, Королівство СХС / Югославія), в умовах посилення зовнішньої загрози протягом усього словенського північного кордону з боку держав, створених мовно неспорідненими народами (італійцями, австрійцями, угорцями), на тій (більшій) частині словенських земель, які стали складовою держави, спільної зі спорідненими слов'янськими народами (хорватами і сербами). В умовах стабільного існування у мультинаціональних державах з авторитарним режимом процес словенського державотворення уповільнювався.

\section{Katerina Malshina}

\section{Slovenian Interwarstate-building: a look through the «windows of opportunities»}

Abstract: The article deals with the restoration of the process of Slovenian statebuilding. was traced; it is proved that the incompleteness of this process was conditioned by following factors: the indecisiveness of the Slovenian national-political program, the split of the Slovenian politicians into the flows of Yugoslavism and Slovenism, which, in turn, rooted in the confidence of the Slovenes in their «non-historicity»; "windows of opportunity» of the state-building process were defined.

The process of restoring Slovenian statehood began in August 1918. After the creation of the Kingdom of SHS (December 1, 1918), the essense of actions of Slovenian politician was the struggle with the central Belgrade government for the preservation of national autonomy. The process passed through four "windows of opportunity» and remained unfinished in the context of the planned fragmentation of Slovenian lands between Italy, Germany, Hungary and Croatia in 1941. 
The Slovenes took advantage of the first «window of opportunity» within the borders of the State of SHS, when the first-ever national democratic authorities were established in August-November 1918. The next «windows of opportunity» was wanted long enough and arose only in 1927-1929, when it was allowed to elect the Ljubljana and Maribor regional assemblies. The third opportunity to continue the state-building process in Slovenia reopened with the creation of the Drava Banovina and its Ban's Council. The Drava Banovina united all Slovenian lands under a single administration, which was a step forward in this respect. The culmination of this process was the preparation for the creation of the Banovina of Slovenia in 1939-1941. The last, fourth, attempt to restore Slovenian national autonomy during the activity of the «April» National Council for Slovenia in the first period of Nazi-Fascist occupation of Slovenia (April - September 1941).

The «windows of opportunity» of the Slovenian state-building process show its «wave» character: it was restored and accelerated in times of internal political chaos - the collapse of multinational state formations within which the Slovenian people lived, amid increasing external threat across the Slovenian northern border, Hungary, in the (most) part of the Slovenian lands, which became part of the state, common with related Slavic peoples (Croats and Serbs). Thus, in the conditions of stable existence in multinational states with an authoritarian regime, the process of Slovenian state formation slowed down.

Keywords: Slovenia, Slovenian state-building, Yugoslavism, Sloveneness, «windows of opportunities» 